\title{
An Experimental Investigation on the Properties of High Volume Flyash Glass Fibre Reinforced Self Compacting Concrete
}

\author{
Chikluru Arifa ${ }^{1}$, K. Mohammed Rasheed ${ }^{2}$, Dr. C. Ramachandrudu ${ }^{3}$
}

${ }^{*}$ M.Tech Student, Chiranjeevi Reddy Institute of Engineering \& Technology, Anantapur, Andhra Pradesh, India

"2 Assistant Professor, Civil Engineering Department, Chiranjeevi Reddy Institute of Engineering \& Technology, Anantapur, Andhra Pradesh, India

3Professor, Civil Engineering Department, Chiranjeevi Reddy Institute of Engineering \& Technology, Anantapur, Andhra Pradesh, India

\section{ABSTRACT}

Civil engineering is a professional engineering discipline that deals with the designing and construction. In construction one of the main resource is concrete in the world. The concrete is day-to-day have many changes like strength, durability, shrinkage. This project deals with the self-compaction concrete with use of fibre reinforcement. The self-compacting in concrete is achieved by adding super plasticizers and glass fibres are used as reinforcement. The influence of including fly ash on the properties of self-compacting concrete is investigated. Fly ash is introduced by $50 \%$ in the total weight of cement. The water to binder ratio was maintained at $0.38 \%$. Properties included workability, compressive strength, split tensile test, modulus of elasticity and shrinkage. The results indicate the high volume FA can be used in SCC to produce the high strength and low shrinkage. Increasing the admixture content beyond the certain level leads to a reduction in strength and increasing in absorption. Making concrete structure without compaction has been done in the past. Like placement of concrete under water by the use of term without compaction. Inaccessible areas were concrete using such a techniques. The production of such mixes use expensive admixtures ad large amount of cement but such type of concrete is low strength. To eliminate such issues lead to the development of selfcompacting concrete (SCC). Usage of fibres makes the mixing of concrete complex. Self-compacting concrete (SCC) is an innovative concrete that does not require vibration for placing and compaction.

Keywords : Compression, Durability, Flyash, Workability, GFRP, Plasticizers, Torsion

\section{INTRODUCTION}

Cement is the main ingredient in concrete production. Concrete is predominant construction material. Infrastructure development around the world created demand for construction material. It was estimated that global production of cement is about 1.3 billion tons in 1996. Production of every point of cement emits carbon dioxide to the tune about 0.87 tons. Expressive it is another way. It can be said that $7 \%$ of the world's carbon dioxide emission is attributable to Portland cement industry. Because of the sufficient contribution to the environmental pollution and to the high consumption of natural resources like limestone etc., we cannot go on producing more and more cement. There is a need to economize the use of cement. One of the practical solutions to optimize cement use is 
replacing pozzolanic industrial waste materials like fly ash.

\section{Fly ash:}

Fly ash is finely divided residue resulting from the combustion of powdered coal and transported by the flue gases and collected by electrostatic precipitator. In U.K. it is referred as pulverized fuel ash (PFA). Fly ash is the most widely used pozzolanic material all over the world. The uses of fly ash as concrete admixture not only expense technical advantages to the properties of concrete but also contributes to the environment pollution control. In India alone, we produced about 75 million tons of fly ash per year, the disposal of which has become a serious environmental problem. The effective utilization of fly ash in concrete making is, therefore, attracting serious consideration of concrete technologists and government departments. In India, the total production of fly ash is nearly as such as that of cement (75 million tonnes). But our utilization of fly ash is only about $50 \%$ of the production. Therefore, the uses of fly ash must be popularized for more than one reason. Concrete is applicable to a variety of constructions due to its flexibility. Cover the past several decades plenty of research was done on the different types of concretes, one of such being roller compacted concrete (RCC). RCC has proved itself to be the best and the economical for mass concreting applications like dams and pavements, due to its rapidity in construction and reduced cementitious material content. SCC as a method evolved both from the efforts of a few concrete dam designers and from the work of geotechnical engineers who traditionally designed earth and rock fill embankments.

\section{SELF-COMPACTING CONCRETE}

Self- Compacting Concrete or SCC is one of the most widely used concrete types mainly because of its selfcompacting characteristics and additional strength benefits. Find out the importance and uses of SelfCompacting concrete along with its manufacturing processes inside the article. Concrete is the most basic element of for any kind of construction work. No matter what type of building structure it is, the concrete used should be study and well compacted. Ensuring the above points not only provide additional strength to the structure but also good finish and appearance to the final product. The compacting of any conventional concrete is done through external force using mechanical devices.

\section{Application of self compacting concrete:}

The development of SCC marks an important milestone in improving the product quality and efficiency of the building industry. SCC can also be used in situations where it is difficult or impossible to use mechanical compaction for fresh concrete, such as underwater concreting, cast in-situ pile foundations, machine bases and columns or walls with congested reinforcements. Recently, this concrete has gained wide use in many countries for different applications and structural configurations as stated by Bouzoubaa (2001). It can also be regarded as "the most revolutionary development in concrete construction for several decades". Originally developed to offset a growing shortage of skilled labour, it is now taken up with enthusiasm across the world for both site and precast concrete work.

\section{FIBRES:}

A glass fibre is a form Glass fibre also called fiberglass. It is material made from extremely fine fibres of glass Fiberglass is a lightweight, extremely strong, and robust material. Although strength properties are somewhat lower than carbon fibre and it is less stiff, the material is typically far less brittle, and the raw materials are much less expensive. Its bulk strength and weight properties are also very favourable when compared to metals, and it can be easily formed using 
moulding processes. Glass is the oldest, and most familiar, performance fibre. Fibres have been manufactured from glass since the 1930s. The fibre reinforced plastic where glass fibre is the reinforced plastic. The glass fibre is usually flattened into a sheet, randomly arranged or woven into a fabric. According to the use of the glass fibre can be made of different types of glass. Fibre glass is light weight, strong and less brittle. The best part of fibre glass is its ability to mould into various complex shapes. This is why fibre glass is widely used in boats, aircrafts, roofing and other applications.

\section{Glass-reinforced plastic:}

Glass-reinforced plastic (GRP) is a composite material or fibre-reinforced plastic made of a plastic reinforced by fine glass fibres. Like graphite-reinforced plastic, the composite material is commonly referred to as fiberglass. The glass can be in the form of a chopped strand mat (CSM) or a woven fabric. As with many other composite materials (such as reinforced concrete), the two materials act together, each overcoming the deficits of the other. Whereas the plastic resins are strong in compressive loading and relatively weak in tensile strength, the glass fibresare very strong in tension but tend not to resist compression. By combining the two materials, GRP becomes a material that resists both compressive and tensile forces well.

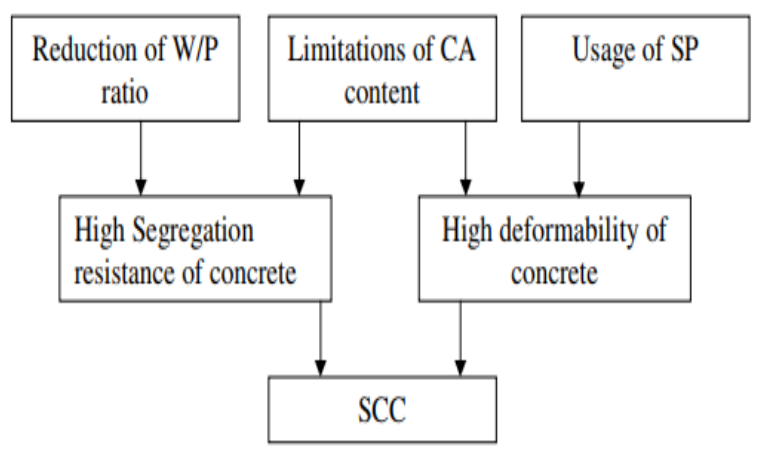

Fig. 1 : Basic principles on SCC

\section{METHODS FOR ACHIEVING SELF COMPACTION}

SCC consists of powder (Cement + filler) in high volume rather than normal concrete; this can be normally achieved with replacement of CA from conventional concrete. This involves high deformability of paste or mortar and resistance to segregation of CA from mortar because concrete has to flow during confined zones and around obstacles like rebars.This in turn is achieved by limiting the aggregate content, using a low water-powder (W/P) ratio and use of a SP. The methodology is shown schematically given by Okamura and Ozawa (1995) as below in Figure.

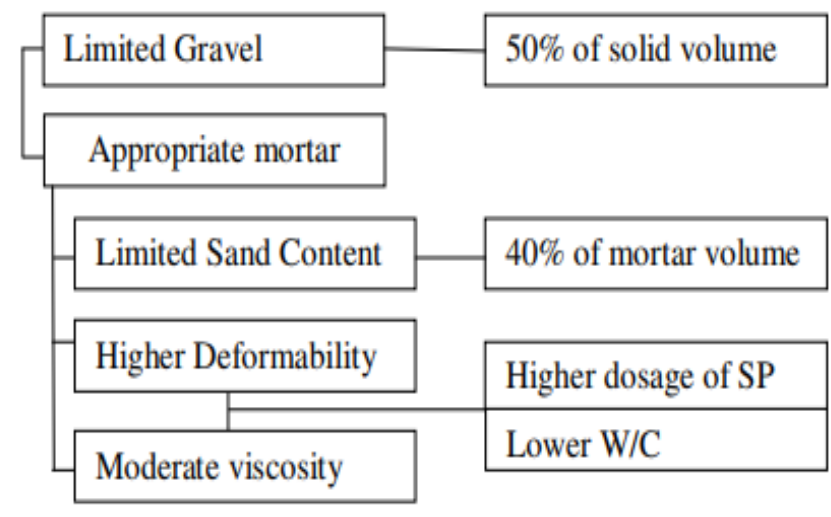

Fig 2 : Methods of achieving SCC

\section{Passing Ability:}

Passing ability is the ability of the concrete to flow though restricted spaces without jamming. This property is related to the maximum aggregate size and aggregate volume, and the L-Box test is the most common method used to evaluate this property. A visualization experiment conducted by Okamura (1997) showed that obstruction occurred from the contact among CA. As the distance between particles decreases, the potential for blocking increases due to particle collisions and the build-up in internal stresses. Decreasing the CA volume can reduce inter- 
particle interaction, and it has been shown that the energy required to initiate flow is often consumed by the increased internal stresses and CA. Hence, Okamura (1997) recommended that the aggregate content should be reduced in order to avoid blockage. The 12 relative displacement from the change in aggregate location causes shear stress in addition to compressive stresses, and in order to flow easily through the narrow spaces the shear stress should be minimized as proposed by Okamura et al (1999).

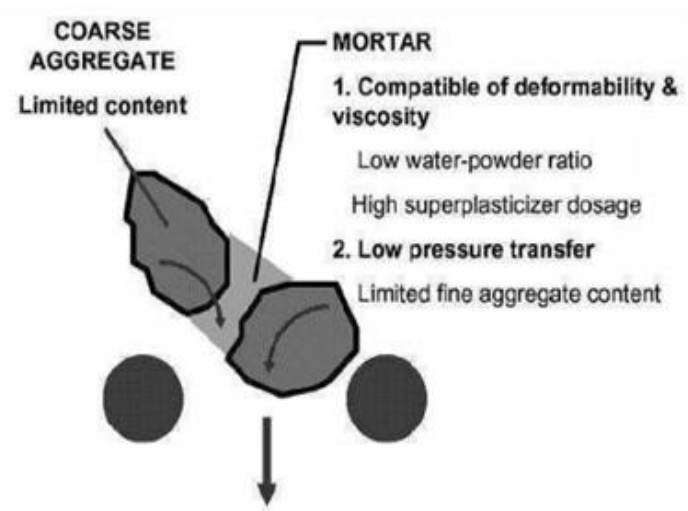

Fig. 3 : Mechanism for achieving Self-Compactability ( Okamura et -1999)

\section{DEVELOPMENT OF SELF COMPACTING CONCRETE}

Kuroiwa [1993], Developed a new type of concrete with materials normally used in conventional concrete, that is, cement, aggregates, water and admixtures. The chemical admixtures were used to improve the deformability and viscosity properties of the concrete. The newly developed concrete was named super-workable concrete. This has shown considerable resistance to segregation and deformability. It also filled heavily reinforced formworks completely without the use of any vibrators. The laboratory tests showed that the superworkable concrete has superior fresh and hardened state properties with improved durability. Because of this, this concrete was considered to be suitable for structures having heavy reinforcement areas and used in the construction of twenty-storied buildings.

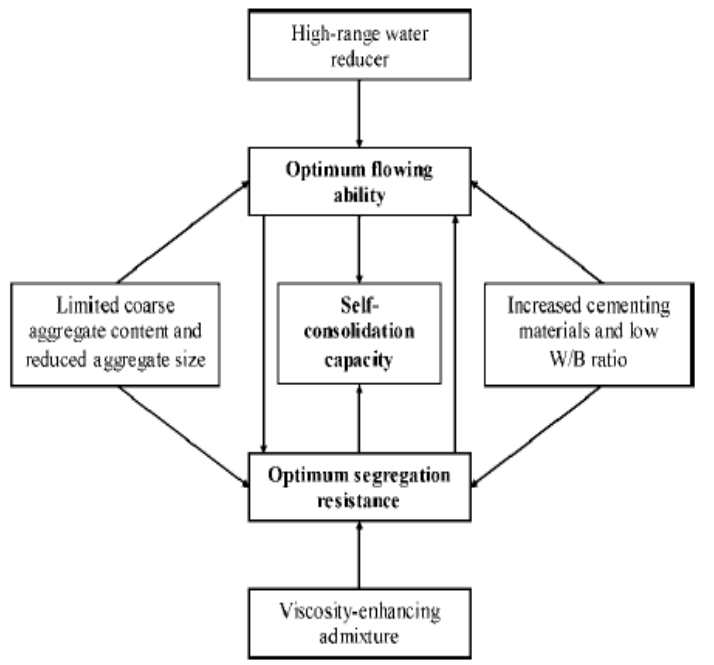

Fig. 4 : Development of SCC

\section{Mix proportioning:}

There are various methods of SCC mix proportioning Mix proportioning was based on the water cement ratio(water/cement + fly ash ratio) and the density of the concrete is $2400 \mathrm{~kg} / \mathrm{m} 3$.for roller compacted concrete i.e. zero slump concrete. Quantity of water required is very less it should be taken as $0.38 \%$ and cement is taken as $450 \mathrm{~kg} / \mathrm{m}$. But in these $50 \%$ of cements is replaced with fly ash. Coarse aggregate is $900 \mathrm{~kg} / \mathrm{m} 3$ and fine aggregate is $900 \mathrm{~kg} / \mathrm{m} 3$.

\section{EXPERIMENTAL PROCEDURE:}

We have assumed a new mix proportions which are by satisfying the workability properties of EFNARC guidelines. First we have done the trial and error method to fix the ratio of water cement and admixture. By using different ratios we got the slump cone flow as $590 \mathrm{~mm}$ at water cement ratio 0.46 . We assumed that the ratio is suitable for mix design.

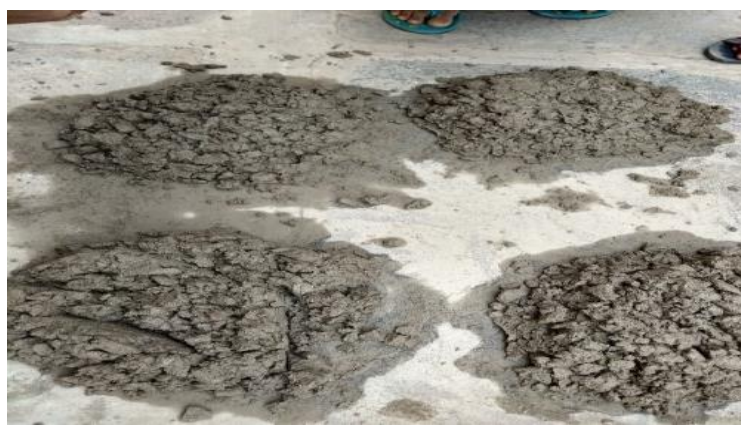

Fig 5 : before adding of super plasticizer 


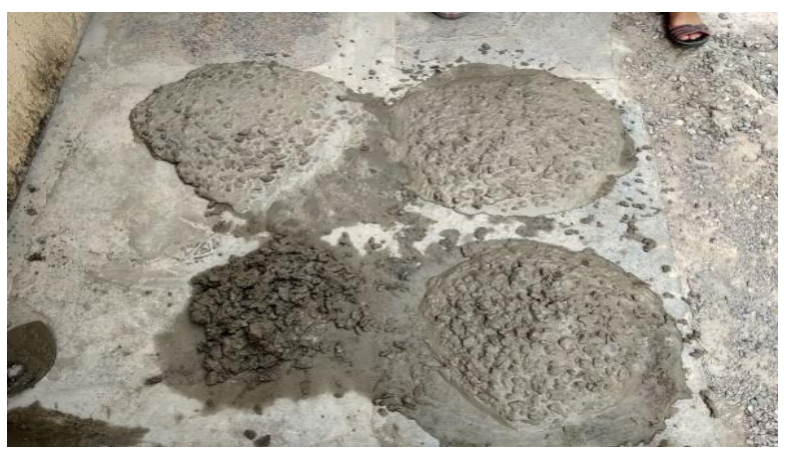

Fig 6 : After adding of super plasticizer

\section{COMPRESSIVE STRENGTH}

Compression test is done confirming to IS:516-1953. All the concrete specimens that are tested in a 2000 KN capacity compression testing machine. Concrete cubes of size $150 \mathrm{~mm} \times 150 \mathrm{~mm} \times 150 \mathrm{~mm}$ and cylinders of size $150 \mathrm{~mm}$ diameter and $300 \mathrm{~mm}$ height and prisms of size $100 \mathrm{~mm} \times 100 \mathrm{~mm} \times 500 \mathrm{~mm}$ were tested for crushing strength, crushing strength of concrete was determined by applying load at the rate of $1400 \mathrm{~N} / \mathrm{Cm} 2 / \mathrm{min}$ till the specimens fail. The maximum load apply to the specimens was recorded and divided the failure load with cross sectional area of the specimens for compressive strength of the concrete.

Compressive strength test was conducted on cubes of $150 \mathrm{~mm} \times 150 \mathrm{~mm} \times 150 \mathrm{~mm}$ cubes and $150 \mathrm{~mm} \times$ $300 \mathrm{~mm}$ cylinders and $100 \mathrm{~mm} \times 100 \mathrm{~mm} \times 500 \mathrm{~mm}$ prisms for the various mixes of the high volume fly ash role compacted concrete.

\section{SPLIT TENSILE STRENGTH}

This test is conducted in a $2000 \mathrm{KN}$ capacity compression testing machine by placing the cylindrical specimen, so that its axis is horizontal to the plates of the testing machine. Narrow strips of packing material i.e., plywood is placed between the plates and the cylinder to receive compressive stress. The load was applied uniformly at a constant rate until failure by splitting along the vertical axis takes place. Load at which the specimens failed recorded and the split tensile stress is obtained using the formula based on IS: 5816-1970.

\section{FLEXURAL STRENGTH TEST}

\section{Reference standards}

IS: 516-1959 - Methods of tests for strength of concrete.

The bed of the testing machine shall be provided with two steel rollers, $38 \mathrm{~mm}$ in diameter, on which the specimen is to be supported, and these rollers shall be so mounted that the distance from centre to centre is $50 \mathrm{~cm}$ for $15.0 \mathrm{~cm}$ specimens or $40 \mathrm{~cm}$ for $10.0 \mathrm{~cm}$ specimens. The load shall be applied through two similar rollers mounted at the third points of the supporting span that is, spaced at $16.67 \mathrm{~cm}$ centre to centre. The load shall be divided equally between the two loading rollers, and all rollers shall be mounted in such a manner that the load is applied axially and without subjecting the specimen to any torsional stresses or restraints.

\section{Third-point loading}

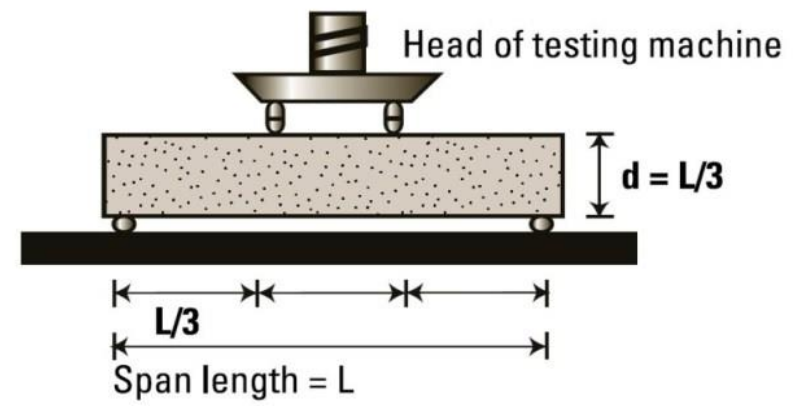

Fig. 7

Flexural Strength $=\frac{\mathrm{Pl}}{\mathrm{b} d^{2}}(M P a)$

\section{REBOUND HAMMER TEST:}

Schmidt' rebound hammer developed in 1948 is one of the common the adopted equipment's for measuring the surface hardness. External view of the hammer as show in fig. 
It consist of spring control hammer that slides on a plunger with in a tubular housing. When the plunger is pressed against the surface of the concrete, the mass rebound from the plunger. It retracts against the force of the spring. The hammer against the concrete and the spring control rebound, taking the rider with it along the guide scale. By pushing a button, the rider can be held in position to allow the reading to be taken. The distance travel by the mass, it is rebound number. It is indicated by the rider moving along a graduated scale.

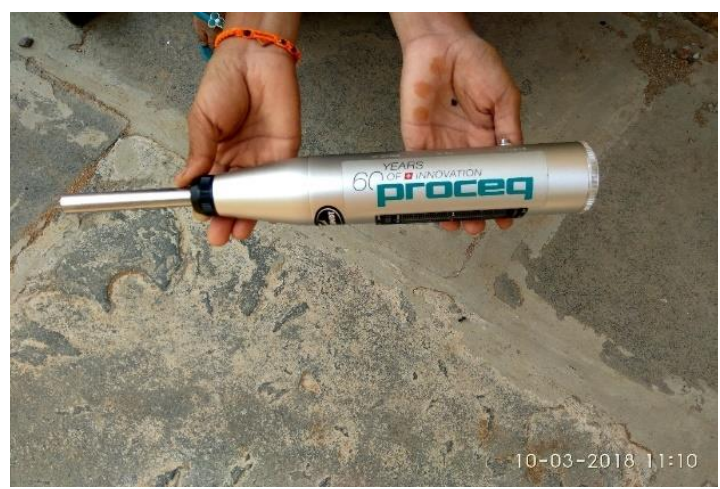

Fig 8 : Rebound hammer

\section{EXPERIMENTAL RESULTS:}

Results and experiments on compressive strength, Split tensile strength, water absorption and evaporation for different fly ash replaced roller compacted concrete have been presented with those of control concrete. For the range of fly ash replaced roller compacted concretes and control mixes studied, the following conclusions can be drawn.

1. The compressive strength was nearly equal to control SCC for $5 \%$ fly ash replacement for 1,7 and 28 days curing ages. Fly ash replacements greater than $20 \%$ have lower strength than conventional concrete.

2. The split tensile strength of fly ash concrete were comparable with conventional concrete up to $5 \%$ fly ash replacement. However, 50\% fly ash replaced concrete had lower split tensile strength than conventional concrete.

3. The results demonstrated that, irrespective of fly ash percentage replacement there was good relationship between compressive strength and split tensile strength.

4. The absorption characteristics shows that the initial $30 \mathrm{~min}$ absorption values for all the concretes were lower than limits commonly associated with good quality concrete. The maximum absorption observed was 3.75\% for $20 \%$ fly ash.

Evaporation of the SCC was comparable with conventional concrete up to $60 \%$ fly ash replacement. However evaporation of $60 \%$ fly ash replaced concrete and 15\% ESP higher than conventional concrete.

Table 1 : Compressive strength for various mixes at $7,14,28$ days

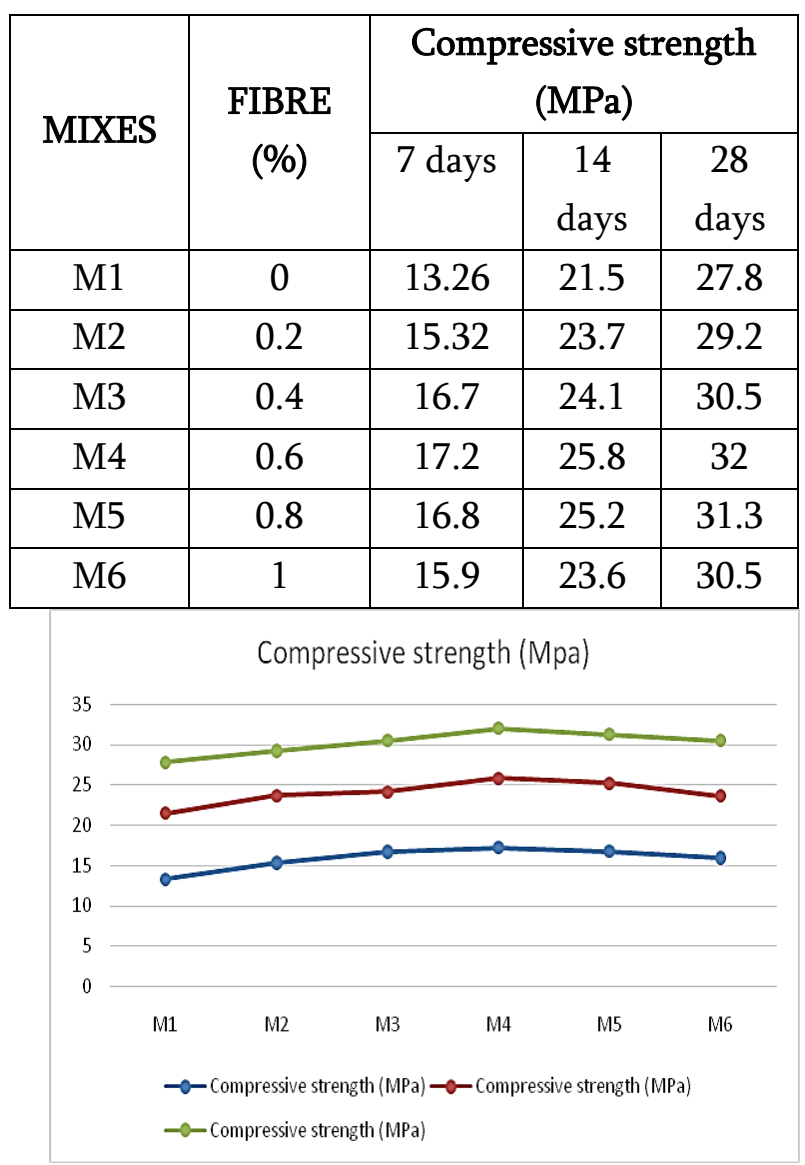


Table 2 : Split Tensile strength for various mixes at $7,14,28$ days

\begin{tabular}{|c|c|c|c|c|}
\hline \multirow{2}{*}{ MIXES } & \multirow{2}{*}{$\begin{array}{c}\text { FIBRE } \\
\text { (\%) }\end{array}$} & \multicolumn{3}{|c|}{$\begin{array}{c}\text { Split tensile strength } \\
\text { (MPa) }\end{array}$} \\
\cline { 3 - 5 } & & 7 days & $\begin{array}{c}14 \\
\text { days }\end{array}$ & $\begin{array}{c}28 \\
\text { days }\end{array}$ \\
\hline M1 & 0 & 2.5 & 4.6 & 6.8 \\
\hline M2 & 0.2 & 2.8 & 5.3 & 7.2 \\
\hline M3 & 0.4 & 3.4 & 5.7 & 7.6 \\
\hline M4 & 0.6 & 4.2 & 6.1 & 8.2 \\
\hline M5 & 0.8 & 4.1 & 5.8 & 8 \\
\hline M6 & 1 & 3.9 & 5.1 & 7.5 \\
\hline
\end{tabular}

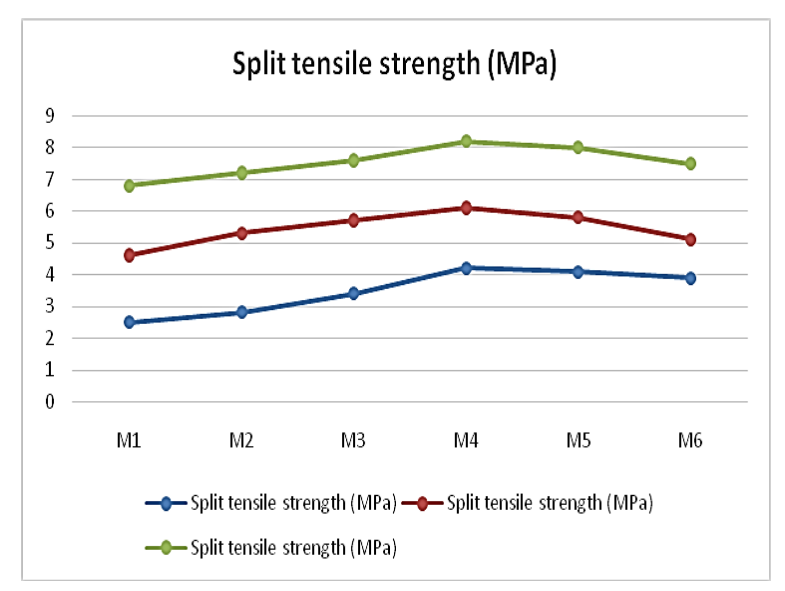

Table 3 : Flexural strength for various mixes at $7,14,28$ days

\begin{tabular}{|c|c|c|c|c|}
\hline \multirow{2}{*}{ MIXES } & \multirow{2}{*}{$\begin{array}{c}\text { FIBRE } \\
\text { (\%) }\end{array}$} & \multicolumn{3}{|c|}{ Flexural strength (MPa) } \\
\cline { 3 - 5 } & 7 days & $\begin{array}{c}14 \\
\text { days }\end{array}$ & $\begin{array}{c}28 \\
\text { days }\end{array}$ \\
\hline M1 & 0 & 4.5 & 6.9 & 8.4 \\
\hline M2 & 0.2 & 4.8 & 7.3 & 8.8 \\
\hline M3 & 0.4 & 5.1 & 7.8 & 9.3 \\
\hline M4 & 0.6 & 5.7 & 8.5 & 9.8 \\
\hline M5 & 0.8 & 5.2 & 8.1 & 9.2 \\
\hline M6 & 1 & 4.7 & 7.6 & 8.4 \\
\hline
\end{tabular}

\section{Flexural strength (MPa)}

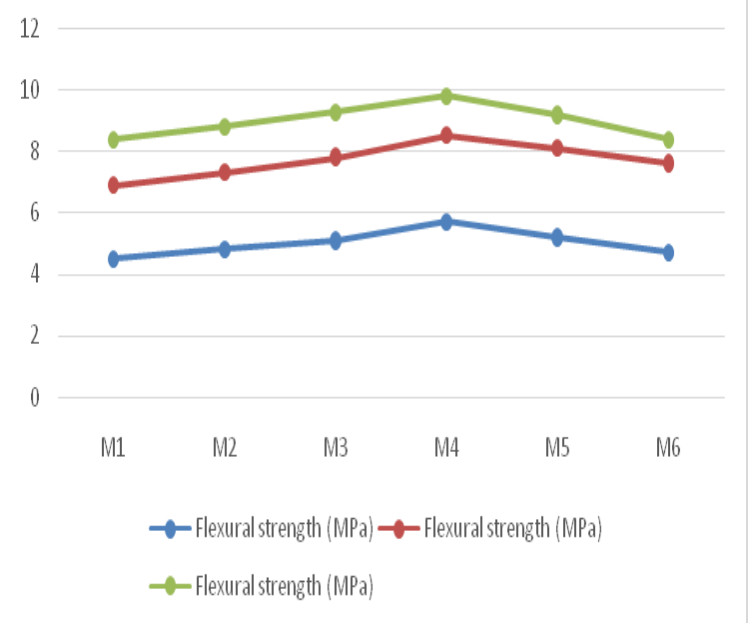

\section{VII.CONCLUSIONS}

1. The workability of fibre reinforced selfcompactingconcrete decreases with increase in the percentage of fibre added.

2. The maximum value of compressive strength was observed at $0.6 \%$ of fibre content at all ages. The compressive strength of concrete decreases with increase in fibre content beyond $0.6 \%$.

3. The maximum value of compressive strength based on rebound hammer test was observed at $0.6 \%$ of fibre content at all ages. The compressive strengthof concrete based on rebound hammer test decreases with increase in fibre content beyond $0.6 \%$.

4. The maximum value of split tensile strength was observed at $0.6 \%$ of fibre content at all ages. The split tensile strength of concrete decreases with increase in fibre content beyond $0.6 \%$.

5. The maximum value of flexural strength was observed at $0.6 \%$ of fibre content at all ages. The flexural strength of concrete decreases with increase in fibre content beyond $0.6 \%$. 


\section{REFERENCES}

[1]. Krishna Murthy. N, Narasimha Rao. A.V, Ramana Reddy I. V and Vijaya Sekhar reddy. M, Mix design procedure for self-compacting concrete, IOSR Journal of Engineering, Vol 2, Issue 9(2012), PP 33-41.

[2]. Zoran Grdic, Iva Despotovic,Gordan Toplicic(2008),Properties of self-compacting concrete with different types of additives, Architecture and Civil engineering Vol. 6,N2,pp 173-177.

[3]. Fareed Ahmed Memon, Muhd Fadhil Nuruddin and Nasir Shafiq (2013), Effects of silica fume on fresh and hardened properties of fly ash based self-compacting geopolymer concrete, International journal of minerals, metallurgy and materials, Volume 20, No 2, Page 205.

[4]. Dhiyaneshwaran. S, Ramanathan. P, Baskar. L and Venkatasubramani. R (2013), Study on durability characteristics of self-compacting concrete with fly ash, Jordan journal of civil engineering, Volume 7

[5]. B. Mahalingam and K. Nagamani(2011), Effect of processed fly ash on fresh and hardened properties of self-compacting concrete, International journals of earth science and engineering, ISSN 0974-5904, Vol. 04, No. 05.

[6]. Kennouche. S, Zerizer. A, Benmounah. A, Hami. B, Formulation and characterization of self-compacting concrete with silica fume (2013)

[7]. Mallikarjuna Reddy. V, Seshagiri Rao. M. V, Srilakshmi. P, Sateesh Kumar. B, Effects of W/C ratio on workability and mechanical properties of High strength self-compacting concrete(2013), International journal of engineering research and development, Vol. 7,Issue 1, PP. 06-13.

\section{Cite this article as :}

Chikluru Arifa, K. Mohammed Rasheed, Dr. C. Ramachandrudu, "An Experimental Investigation on the Properties of High Volume Flyash Glass Fibre Reinforced Self Compacting Concrete", International Journal of Scientific Research in Science and Technology (IJSRST), Online ISSN : 2395-602X, Print ISSN : 2395-6011, Volume 6 Issue 2, pp. 650-657, March-April 2019. Available at doi : https://doi.org/10.32628/IJSRST1962140 Journal URL : http://ijsrst.com/IJSRST1962140 